\title{
The Advent of Heroic Anthropology in the History of Ideas
}

\author{
Albert Doja
}

Introduction

It is sometimes claimed that Radcliffe-Brown and Malinowski more or less single-handedly created modern anthropology. This may have seemed to be the case at midcentury, when Boasian American anthropology had diverged out into many specialized strands and Marcel Mauss's students had not yet made their mark in French anthropology. British kinship studies seemed, in contrast, to rest securely on a method invented by Malinowski and a theory developed by Radcliffe-Brown, as an established "science of society." As Eriksen and Nielsen put it, major changes took place in anthropology during the 1950s and 1960s, economics and politics were reconceptualized and new theories of symbolic meaning transformed the discipline. ${ }^{1}$ Developments in North America and Britain differed, although the problems raised were similar, yet the single most important theorist was French.

If already in the first postwar years, Claude Lévi-Strauss will emerge as an exemplary thinker, the most important figure in the history of anthropology and the "ecumenical," "paradigmatic anthropologist" of the second half of the twentieth century, this implies a good deal about the intellectual milieu of our time and of anthropology in particular. ${ }^{2}$ In the 1950 s and 1960 s, for a number of reasons, not the least of which is Lévi-Strauss's astute promotion

${ }^{1}$ Thomas H. Eriksen and Finn S. Nielsen, A History of Anthropology (London: Pluto Press, 2001), 95.

${ }^{2}$ Stanley Diamond, "The Inauthenticity of Anthropology: The Myth of Structuralism," in In Search of the Primitive: A Critique of Civilization (New Brunswick, N.J.: Transaction Books, 1974), 292-331. 
of his discipline, ${ }^{3}$ anthropology becomes one of the essential reference points of intellectual discourse in France, taking part of the mainstream of ideas defined as structuralism, which had the ambition to provide social sciences a rigor and power comparable to those of natural sciences.

Moreover, the "unparalleled" intellectual and international prominence and audience Lévi-Strauss has acquired in anthropology has been immensely influential, not only in anthropology, but in the disciplines interested in mankind and human products, from history and psychoanalysis to philosophy and literary studies. "The bearing of that work on the notion of culture, on our understanding of language and mental processes, on our interpretation of history is so direct and novel that, George Steiner claimed, an awareness of LéviStrauss's thought is a part of current literacy." "His work has brought about an epistemological break with previous methods of analysis, so as one can refer to a real anthropological revolution.

What is often ignored is the extent to which Lévi-Strauss's original formulation of structural method was embedded in problems specific to the position of anthropology, not simply problems of anthropological theory, but more generally problems of definition of the nature and scope of anthropology and its relationship with the other human sciences. It seems that Lévi-Strauss is always concerned with asserting something more general about the nature of the discipline he is practicing, its field of reference and its claims to scientific and humanistic interest, in an essentially "corporatist" way of thinking. $\mathrm{He}$ is not content simply to speak on his own account and from his own local perspective, but is also prepared to speak collectively, in the name of anthropology, in defence of what he believes to be its special contribution to contemporary knowledge, to the extent that the advent of his contribution has done "more to alter anthropology's sense of itself than its sense of its sub-

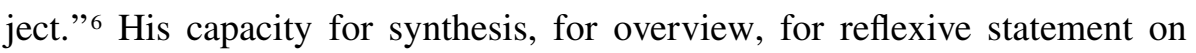
what one's discipline is about and also what it should be about, could be seen as an essential trait of Lévi-Strauss, who is not simply a producer of ideas and theories, but equally and inseparably, an influential thinker, maître à penser.

Lévi-Strauss developed anthropology into a scientific project with far more sophisticated intellectual purchase for understanding humanity than is generally acknowledged or than the discipline had previously achieved. His contribution represented the reabsorption of the discipline into the mainstream

${ }^{3}$ Christopher Johnson, Claude Levi-Strauss: The Formative Years (Cambridge: Cambridge University Press, 2003), 29.

${ }^{4}$ George Steiner, Language and Silence: Essays on Language, Literature, and the Inhuman (London: Faber, 1967), 250.

${ }^{5}$ Johnson, Claude Levi-Strauss, 181.

${ }^{6}$ Clifford Geertz, Works and Lives: The Anthropologist as Author (Stanford, Calif.: Stanford University Press, 1988), 25. 
of Western ideas, since he reestablished anthropology as an intellectual undertaking, a profession of the intelligentsia, rather than a specialized vocation with its own peculiar language, corpus of data, techniques, methods, and theory. The rise of structuralism itself is historically inseparable from the prestige of anthropology. Structuralism became an alternative to Marxism and phenomenology, and its impact on general intellectual life was at least as pronounced as in anthropology. In France, important scholars like Lacan, Barthes, Foucault, and Bourdieu were brought up on structuralism, eventually rebelled against it, and their rebellion was in turn noted and debated by anthropologists, who brought these authors into the canon of anthropology.

\section{The Intellectual Context}

In France, with the publication of Being and Nothingness and the Phenomenology of Perception, phenomenology dominated the intellectual life in the form of existentialism, which became an all-encompassing philosophical movement under the charismatic leadership of Jean-Paul Sartre. ${ }^{7}$ The phenomenon of structuralism captured the attention of Parisian intelligentsia in the late 1950s and the 1960s and set the terms of intellectual debate for the entire decade. The debates that developed around existentialism and structuralism in the 1960s provide a typical dialectical counterpointing of schools or movements that seems to be a permanent feature of French intellectual life. ${ }^{8}$ With its combination of science and humanism, structuralism was seen as the logical successor to existentialism. The first volume of Lévi-Strauss's Structural Anthropology $y^{9}$ in some way appeared at the time as the manifesto of structuralism, and already Lévi-Strauss was spoken of as a philosopher, the founder of structuralism, on a par with Sartre, the founder of existentialism.

Structuralism was a reaction against the predominantly phenomenological bias of French philosophy in the postwar years. In this sense, it is impossible to understand the phenomenal success of structuralism in France without reference to the previous hegemony of existentialism, of which it appeared to be a point-by-point refutation. Basically, postwar philosophers, of the same generation as Lévi-Strauss, formulated the same objections as him with regard to traditional philosophy, that is, resting on a system of factitious and insurmountable oppositions between subject and object that always renew the same narrow conceptions and hamper any investigation. But to a conscience reduced to "I think," inherited from Cartesianism, phenomenology substituted

${ }^{7}$ Jean-Paul Sartre, L'Etre et le Neant: essai d'ontologie phenomenologique (Paris: Gallimard, 1943); Maurice Merleau-Ponty, Phenomenologie de la perception (Paris: Gallimard, 1945).

${ }^{8}$ Johnson, Claude Levi-Strauss, 107-8.

${ }^{9}$ Claude Lévi-Strauss, Anthropologie structurale (Paris: Plon, 1958). 
a conscience widened toward body experience and history ordeals. The subject is apprehended on the level of its perceptions and its experiences. The cogito of Descartes made place to a percipio with Merleau-Ponty, a praxis with Sartre, or a gramma with Derrida. Moreover, whereas Sartre's existentialism and Derrida's grammatology could be situated within a recognizable tradition of Western philosophy, taking their inspiration from the phenomenology of Husserl and Heidegger, for Lévi-Strauss the program of structural anthropology and the social sciences represented a break with metaphysics, a rejection of the traditional problems of philosophy in order to pursue a scientific investigation of human behavior.

Structuralism was above all an expression of contest and corresponded to a moment of Western history as an expression of a certain amount of detestation of self, rejection of traditional Western culture, and wish of modernism in a search for new models. Structuralism opposed to the glorification of old values a certain sensitivity for everything repressed in Western history, the reverse of manifest meaning, the repressed and inaccessible side of human nature. Foucault, in his Order of Things, aptly described Lacan's psychoanalysis and Lévi-Strauss's anthropology as animated "by a perpetual principle of anxiety, of setting in question, of criticism and contestation of everything that could seem, in other respects, as taken for granted." ${ }^{10}$ From this point of view, Lévi-Strauss's very choice of the linguistic model is by no means indifferent, for one of the revolutionary principles structural linguistics has introduced in scientific methodology was exactly to shift the inquiry from the level of conscious linguistic phenomena to that of their unconscious infrastructure. The means of conceptualizing the relations not immediately available to conscious intuition that structural analysis uncovers, as proposed by Lévi-Strauss, is intuitively the most assimilable representation of the unconscious. ${ }^{11}$

The decline of the European powers and the wave of decolonization that followed the war had the result for many to question the preeminence of European culture and consciousness and also to criticize its ethnocentrism. In this context it seemed logical that anthropology, in its special role as mediator of non-Western cultures, should become the special focus of such questioning and criticism. Indeed, structural anthropology is justified as a human science of non-Western cultures in light of their modern experience of alienation, in what amounts to an alternative form of humanism. This new humanism, which Lévi-Strauss aimed to extend "to the measure of humanity," combines the ambition of scientific analysis with the imperative of a global awareness. ${ }^{12}$

${ }^{10}$ Michel Foucault, Les mots et les choses: une archeologie des sciences humaines (Paris: Gallimard, 1966), 385.

${ }^{11}$ Claude Lévi-Strauss, "L'analyse structurale en linguistique et en anthropologie," in Anthropologie structurale (Paris: Plon, 1958), 40.

${ }^{12}$ Claude Lévi-Strauss, "Le champ de l'anthropologie," in Anthropologie structurale deux (Paris: Plon, 1973 [New York: Basic Books, 1976]), 44 [32]. 
A wider vision of humanity than the traditional philosophical version of humanism involved, focused on the conception of the individual subject as culture-specific, is thus far from achieving the kind of universality that the old humanism claimed.

In effect, the old humanism, as exemplified in the figure of Sartre, seemed by comparison parochial both in its confinement to a specific tradition of Western philosophy and in its lack of interest in the developments of contemporary science. The new humanism of Lévi-Strauss's anthropology was seen to combine the rigor of science with an enlarged vision of humanity, acting as both the conscience and the consciousness of Western civilization, while assigning a humbler role to the individual subject.

In this sense, the scientific mission of structural anthropology cannot exclude consideration of questions of value and ideology. For Lévi-Strauss, structural anthropology as a human science and humanism are not antinomic. The close articulation of the epistemological and the ethical in Lévi-Strauss's work, in the way he articulates his life experience and his theoretical work, possesses a heuristic closure and methodological unity that transcends the narrowly scientific program of structuralism. Indeed, it is apparent that the paradigm of structural anthropology cannot simply be equated with the field of structuralism, and that it amounts to something altogether more complex.

From the 1960s, structuralism was to flourish in many other fields and very rapidly became a form, often very contestable, of an intellectual, philosophical, and literary fad, with all of the distortions and simplifications that accompany such popularization. Lévi-Strauss never therefore failed to distance himself from and deny paternity of the ideological passions that gave raise to the structuralist vogue. He has endlessly repeated that structuralism, as it developed in France in the late 1950s and early 1960s, should be distinguished from what he was attempting to accomplish in anthropology.

Often he was summoned to describe fields of knowledge that were not familiar for him, methods that he could not recognize, or standpoints that had nothing to do with the technical character of his own research. Finally, he very quickly understood of such intellectual fashions to what extent they could publicly and academically harm the rigor and the serene evaluation of his own work. That is why he chose for the most part to keep himself away from this intellectual agitation. Undoubtedly anxious to police his inheritance, he limited himself to correcting what he perceives as misinformed attacks on his own local practice of structural analysis, and engaged his dialogue in debates only with those, either in anthropology or in close disciplines, who posed to him or to themselves precise questions and raised relevant objections.

For Lévi-Strauss, structuralism was only the narrow framework of a brilliant venture. Essentially, his work is at once more modest, more scrupulous, and much more relevant for anthropological knowledge, even if the style remains a baroque mixture of equilibrium and witty liveliness. Even if structur- 
alism might have once had a beneficial role, it became nowadays an obstacle to the full development of ideas for which anthropology is after all indebted to Lévi-Strauss. His approach came less from general principles than from a demanding and audacious intellectual attitude. Thanks to this attitude and a number of deep intuitions, theoretical work offered him the appealing opportunity to hunt for order within chaos and make a very general and at the same time very personal contribution to anthropology.

If the structural anthropology consists in studying rules and showing laws, in particular by the analysis of certain aspects of social life or cultural materializations whose validity could be tested on other aspects, it is not a question of an ideological structuralism that would bring a message or offer a general philosophy of man. The epistemological approach of Lévi-Strauss has the ambition to be only a rigorous method that comes close to scientific knowledge, and quite simply to introduce a measure of rigor in an area of study where there had been none. Certain passages of his work undoubtedly verge on the excess of methodological optimism, the structural analysis seeming to merge with science itself, whose royal way, mathematics included, finally opened to the fields that until now have remained rebellious. But he never confused with the outline of a new dogmatic system of scientist inspiration certain more personal digressions, which he pleasantly qualifies as "a little poaching on the hunting territory kept by philosophy," in spite of the range and depth of sights they may express.

The absorption and development of Lévi-Strauss's stimulating and contentious theories engaged the attention of a number of talented anthropologists not only in France but also in Britain and elsewhere. It is one of the ironies of the history of the reception of Lévi-Strauss's work in anthropology that he has sometimes been reproached by his French colleagues for his undue attachment to the "Anglo-Saxon" tradition, while his English-speaking colleagues have criticized his "French" penchant for speculation, abstraction, and generalization. ${ }^{13}$

Even though British anthropology is traditionally used to receive theories from France, Lévi-Strauss's work reached such a degree of abstraction that the quasi-natural British circumspection could only be overcome in good measure thanks to the witty eloquence of an Edmund Leach. Among other things, when introducing a collection of papers by British anthropologists dealing with Lévi-Strauss's theories of myth and totemism, Leach went on to comment that some of the contributors did not appear to have read Lévi-Strauss, and that their criticism depended "either on English arrogance or straight misinformation." ${ }^{14}$ It is Leach's introduction to the writings of Lévi-Strauss,

${ }^{13}$ Johnson, Claude Levi-Strauss, 9.

${ }^{14}$ Edmund R. Leach (ed.), The Structural Study of Myth and Totemism, A.A.A. Monographs, 5 (London: Tavistock, 1967), xv. 
perhaps the most widely read, that substantially increased knowledge of LéviStrauss's work in the English-speaking world. ${ }^{15}$

Leach has been the most enthusiastic and creative of the leading British anthropologists who experimented in applying structural methods to new subjects, doing much enough to make structural ideas accessible. ${ }^{16}$ Lévi-Strauss himself had commented quite extensively on kinship among the Kachin, and Leach immediately recognized not only the relevance of Lévi-Strauss's conclusions for his own data. ${ }^{17}$ As he later confessed, "what amazed me at the time was that Lévi-Strauss had somehow perceived much more clearly than I had myself certain essential features of the structure of Kachin society." 18 Rodney Needham was another early enthusiast for Lévi-Strauss, although he had certain reservations, strengthened by Lévi-Strauss himself, who strongly repudiated Needham's interpretation of his kinship theory. All reservations were far from being dissipated, and in what took sometimes the forms of a great national cause, many British anthropologists criticized Lévi-Strauss rather vehemently. Definitely more positive, Leach also was not less polemist, and sometimes even provocative.

In structuralism, however, Leach and others discovered a sophisticated alternative to British empiricism. Not surprisingly, the British passion for Lévi-Strauss's structural anthropology was accompanied by a quasi-visceral rejection of Radcliffe-Brown's structural-functionalism. Needham ${ }^{19}$ dedicated to the latter a morbid resentment, while in his British Academy RadcliffeBrown Lecture, Leach ${ }^{20}$ made of his admiration for Lévi-Strauss the corollary of a contempt for Radcliffe-Brown. The success in converting some of the brightest students of the period was facilitated by the almost religious enthusiasm of Leach and Needham, joined later by Mary Douglas, ${ }^{21}$ in propagating of Lévi-Strauss's ideas.

Structuralism came to have something of the momentum of a millennial movement, and some of its adherents felt that they formed a

${ }^{15}$ Edmund Leach, Claude Levi-Strauss (London: Fontana/Collins, 1970).

${ }^{16}$ Edmund Leach, Culture and Communication: The Logic by which Symbols are Connected (Cambridge: Cambridge University Press, 1976).

${ }^{17}$ Edmund Leach, Political Systems of Highland Burma: A Study of Kachin Social Structure (Cambridge, Mass.: Harvard University Press/London School of Economics and Political Science, 1954).

${ }^{18}$ Edmund Leach, "Telstar et les aborigines ou la Pensee sauvage," in Anthropology and Society, ed. Stephen Hugh-Jones and James Laidlaw (New Haven, Conn.: Yale University Press, 2000), 121.

${ }^{19}$ Rodney Needham, Structure and Sentiment: A Test Case in Social Anthropology (Chicago: University of Chicago Press, 1962).

${ }^{20}$ Edmund Leach, "Social Anthropology: A Natural Science of Society? [British Academy Radcliffe-Brown Lecture]," in Anthropology and Society, ed. Stephen Hugh-Jones and James Laidlaw (New Haven, Conn.: Yale University Press, 2000).

${ }^{21}$ Mary Douglas, Purity and Danger: An Analysis of Concepts of Pollution and Taboo (London: Routledge \& Kegan Paul, 1966). 
secret society of the seeing in a world of the blind. Conversion was not just a matter of accepting a new paradigm. It was, almost, a question of salvation. ${ }^{22}$

The United States were undoubtedly less permeable to the ideas and theories of the great French anthropologist, even though Lévi-Strauss "as self-incorporated Americanist" may be considered to some extent as successor to the Boasian tradition. ${ }^{23}$ As Adam Kuper rhetorically reminds us, who but Boas would have bothered to publish pages and pages of Kwakiutl gooseberry pie recipes in vernacular language, and who but Lévi-Strauss would be interested in reanalyzing such material?24 Admittedly, analyses and criticism of LéviStrauss have been common enough and his work was discussed by American anthropologists as by many others. Perhaps the most encompassing is the chapter on the "cerebral savage" written by Clifford Geertz who presents an original reading of Lévi-Strauss's work. ${ }^{25}$ Marshall Sahlins, initially influenced by structural Marxism and neo-evolutionism, is one of the first who, in his radical criticism of Marxism as unable to account for the foundations of "tribal society," considered structuralism as advancement in this respect. ${ }^{26}$ Although still thought to be unable to seize change "the structure is the beginning of historical wisdom," and Sahlins was one of the first who tried to make structural anthropology historical. ${ }^{27}$

Nevertheless, the country of culturalism seemed uneasy with the idea that the logic of symbolism could derive from the human mind. Most AngloAmerican anthropologists were in fact deeply suspicious of Lévi-Strauss. Although challenged by his suppositions, they become outraged by the selectivity with which he handles his data; attracted by his brilliant literary style, they were angered by the arrogance they see as contradicting his humanism; and invited by his philosophical inquiries, they felt disbelief and almost embarrassment when confronting the narrowness to which his concept of structure reduces to a layered grid the problems of human symbolicity and history. ${ }^{28}$ To a great extent all were provoked by Lévi-Strauss's abstract models and deduc-

${ }^{22}$ Adam Kuper, Anthropologists and Anthropology: The Modern British School, 3rd ed. (London/New York: Routledge, 1996), 215.

${ }^{23}$ Regna Darnell, Invisible Genealogies: A History of Americanist Anthropology (Lincoln: University of Nebraska Press, 2001), 282.

${ }^{24}$ Kuper, Anthropologists and Anthropology, 223.

${ }^{25}$ Clifford Geertz, The Interpretation of Cultures (New York: Basic Books, 1973), $345-59$.

${ }^{26}$ Marshall D. Sahlins, Culture and Practical Reason (Chicago: University of Chicago Press, 1976).

${ }^{27}$ Marshall Sahlins, Historical Metaphors and Mysthical Realities: Structure in the Early History of the Sandwich Islands Kingdom (Ann Arbor: University of Michigan Press, 1981).

${ }^{28}$ Eleanor B. Leacock, "Structuralism and Dialectics," Reviews in Anthropology, 5 (1978), 117-28. 
tive thinking, and although they disagree with his unfamiliar assumptions about marriage or tendentious summaries of selected myths, most remain caught by his seductive style, interweaving as he does broad philosophical considerations, concise theoretical statements, and the fascinating exploratory discussion of mythic and social materials. Clifford Geertz, for instance, in spite of his own "admitted scepticism toward the structuralist project as a research program" and his probably "outright hostility to it as a philosophy of mind," makes it clear that he regards Lévi-Strauss's "construction of an entire discourse realm from a standing start as a stunning achievement, altogether worthy of the attention it has received." 29

\section{The Antistructural Critique}

Lévi-Strauss was from the beginning a controversial and influential author, and his challenge to what remains a generally positivist anthropology continues to be enormously influential. In spite of the enormous secondary literature, debate still rages over the validity of Lévi-Strauss's methods, which may sound plausible in theory but there are practical difficulties that turn out to be of major importance.

Critiques of Lévi-Strauss's work fall into two main classes, as adversaries of the method deplore not only structuralism's apparent indifference to history but also its restrictive model for consciousness and its empirical inadequacy. A first serious objection, initially expressed in the polemic raised by Jean-Paul Sartre in his Critique of Dialectical Reason, related to LéviStrauss's limits of the meaning of history. ${ }^{30}$ The most devastating critique came from Jacques Derrida in his Grammatology, who emphasized the elaborate and illusory formalism of structuralism's purported universals as exemplary only of the fallacies of the Western "phonologistic" and "logocentric" philosophical tradition. ${ }^{31}$ Again and again Derrida methodically attacked structuralism and the whole range of Lévi-Strauss's work and accused structuralism of failing to acknowledge the free "play" of the signifier. ${ }^{32}$

It is on the issue of relationship between subject and object that the dissension is the most acrimonious, the philosophers suspecting Lévi-Strauss to reduce man and his works to a purely objective reflection. From the point of view of phenomenology, they blame out the structural approach for impoverishing social praxis or for being unable to reach the interpretative dimension of comprehension. Exported in the English-speaking world, the critical question became that of agency, of who uses what, and to what extent "what"

\footnotetext{
${ }^{29}$ Geertz, Works and Lives, 27.

${ }^{30}$ Jean-Paul Sartre, Critique de la raison dialectique (Paris: Gallimard: 1960).

${ }^{31}$ Jacques Derrida, De la grammatologie (Paris: Minuit, 1967).

${ }^{32}$ Jacques Derrida, L'ecriture et la difference (Paris: Seuil, 1967), 409-28.
} 
may become independent of "who." Essayists and philosophers of various horizons condemned structural analysis as a doctrine of refuting any freedom to the subject of meaning production and any autonomy to individual praxis, human agency becoming entirely dependent in the apprehension of reality and self-consciousness on the universal laws of an already constituted reason.

Whereas Sartre's brand of existentialism was primarily concerned with the experience of the subject in-the-world, stressing the importance of historical situation and the necessity of individual choice and responsibility, structuralism focused on the unconscious structures that precede individual agency and resist historical contingency, and at least in principle, was said to remain closed to questions of a moral or ethical nature. Sartre criticized the abstraction of structural analysis and its objectification of human experience, which ignored the dialectical realties of concrete relations and historical processes. ${ }^{33}$ In his view the priority given to autonomous and unconscious structures dehumanized the subject and excluded the possibility of individual agency. ${ }^{34}$ The "death of the subject" was, in fact, a favorite theme in French structuralism during the 1960s. Regarding the nature of Lévi-Straussian isomorphism between the laws of the universe and those of the mind, Paul Ricoeur assumed from the start that what was being proffered was a Kantian unconsciousness.

Not the Freudian unconscious of instinctual, erotic drives and its power of symbolisation, but a categorial, combinative unconscious, as regards its organization, since we are here concerned with a categorial system without reference to a thinking subject; that is why structuralism as a philosophy will develop a kind of intellectualism which is fundamentally anti-reflective, anti-idealist and anti-phenomenological. $^{35}$

Structures move toward concordance by mutually reflecting hypothesized underlying predispositions of the mind, and by reflecting each other in various ways. In Lévi-Strauss's scheme there seems to be not developmental change, but mere permutation and combination. In Tristes Tropiques, when he related Marxism to the other main impulses in his own intellectual development and conception of ethnography, he was concerned with the same primary question: "That of the relationship between feeling and reason, the experienced and the rational, and the aim pursued is the same: to achieve a kind of superrationalism which will integrate the former with the latter without sacrificing any of its properties." 36

${ }_{33}^{33}$ Jean-Paul Sartre, Critique de la raison dialectique (Paris: Gallimard, 1985), 490-93.

${ }^{34}$ Jean-Paul Sartre, "L'anthropologie," in Situations (Paris: Gallimard, 1972), 9: 83-89.

${ }^{35}$ Paul Ricoeur, Le conflit des interpretations: essais d'hermeneutique (Paris: Seuil, 1969), 37.

${ }^{36}$ Claude Levi-Strauss, Tristes Tropiques (Paris: Plon, 1955), 62. 
This may be a very abstract way of saying that Marxism is an etiology, an attempt to trace the conditions of society, of material environment, and of human consciousness, to their hidden source. Social relations and collective representations are then the primary coordinates of Lévi-Strauss's theory, who goes on to suggest that Marxism itself is only a partial case of a more general theory of communication. This theory will be the framework of a truly rational and comprehensive sociology. Not surprisingly, Marxists have challenged the "totalitarian" claims of Lévi-Strauss's theory and have attacked its "irrationalist" and "anti-historical" aspects.

It was not enough to simply posit kinship structures or mental frameworks; equally important is the process by which these are produced and reproduced. With kinship, Lévi-Strauss had addressed the issue with an emphasis on reciprocity and cross-cousin marriage. But by shying away from it in his studies of the intellect, with his formula of "forms imposed upon content," ${ }^{37}$ Lévi-Strauss is believed to have fallen victim to his own method$\operatorname{ology} .38$

At any rate, if both Lévi-Strauss's and Marx's methods emphasize the determinateness of underlying hidden structures, today this may amount to little more than scientific truism. Structuralism seems to deny meaning to surface phenomena, such as social action and praxis, because it views meaning as a faculty of deep structure not susceptible to modification through experience. The divorce of structural analysis in its Lévi-Straussian form from all these sets of considerations, like the divorce of structure itself from the individual social and cultural forms that are its putative bearers, is believed to be a result of Lévi-Strauss's a priori commitment to Saussurean ideology. ${ }^{39}$ Displacing the concept of structure outside any concrete cultural construct means, in effect, that any social or cultural system is separated by definition from any articulation with subjective consciousness, interpretive meaning, social action, or social organization. These separations thus converge with the fundamental antinomies of Saussurean linguistic ideology, inter alia the separation of cognition from action, culture from society, paradigm from syntagm, text from context, structure from historical process, and subjectivity from the structures of consciousness.

In addition, considering that Lévi-Strauss borrowed his most essential claims for structural analysis from linguistics, critics see as a paradox that language, the subject matter of linguistic discipline, failed utterly to engage his imagination. Some claim that he failed, like Durkheim, to address the

${ }^{37}$ Claude Levi-Strauss, "Histoire et ethnologie," in Anthropologie structurale (Paris: Plon, 1949), 28.

${ }^{38}$ Gary Roth, "Claude Levi-Strauss in Retrospect," Dialectical Anthropology, 18 (1993), 31-52.

${ }^{39}$ Terence S. Turner, "On Structure and Entropy: Theoretical Pastiche and the Contradictions of Structuralism," Current Anthropology, 31 (1990), 563-68. 
contention of historical linguistics that the comparative method provides the closest thing to a "scientific" method attainable to the social sciences. ${ }^{40}$ Others believe that he virtually ignores language as a system of communication, whereby symbols are created and manipulated in the process of persuading and admonishing, seeking reassurance, catharsis, straightforward enjoyment, or attempting to comprehend situations. There is no place in his explanations for the emotions, the wonderful, joy, sorrow, and love. Although ever occupied with meanings, he is supposed to reduce semantics to a mere tool for discovering binary structures. His work is based on the universality of metaphor, yet he treats metaphor as given, as virtually coterminous with the physiological structure of the brain, rather than as a powerful artifice of language. ${ }^{41}$ Most consider thereby a largely misunderstood model of linguistic structure altogether with a separation of myth from other language products, in which Lévi-Strauss's mechanistic views of social systems is allegedly matched.

In this line of criticism there is also the closing off of the question of ritual. The accusation, coming mainly from British anthropologists like Victor Turner, is that his exclusive concentration on the symbolic and the cognitive has neglected the reality of the extreme affective states experienced during social activities like ritual, which cannot simply be reduced to modalities of the intellect. ${ }^{42}$

More importantly, it is significant for critics that in defining the critical role of anthropology, Lévi-Strauss avoids all mention of social processes such as exploitation, alienation, the extreme division of labor, modern war, and the character of the state. ${ }^{43}$ Given his affinity with Marxism, Lévi-Strauss was also expected to search for the basis of universal structures in the quality of material life, not just in economic activity but in the complete dimensions of social life which constitute the fabric of human activity. ${ }^{44}$ But having contributed to the resurgence of both Marxist anthropology and literary criticism, he ended by ignoring them both. And despite his claims of shifting from infrastructural to superstructural concerns, he is actually reproached to fall into neither area.

His thirst for the ultimate is supposed to evade our realities or, perhaps, to take them for granted as mere contingencies. Apparently, in the Mythologiques cycle, ${ }^{45}$ the relationships of myths to the people who work them out are only examined quite occasionally, and the structural perspective is vehe-

${ }^{40}$ Regna Darnell, "The Structuralism of Claude Levi-Strauss," Historiographia Linguistica: International Journal for the Historyof the Language Sciences, 22 (1995), 217-34.

${ }^{41}$ Leacock, "Structuralism and Dialectics."

42 Victor W. Turner, The Ritual Process: Structure and Anti-Structure, The Lewis Henry Morgan Lectures, 1966 (Chicago: Aldine, 1969).

${ }^{43}$ Diamond, "The Inauthenticity of Anthropology."

${ }^{44}$ Roth, "Claude Levi-Strauss in Retrospect."

${ }^{45}$ Claude Lévi-Strauss, Le Cru et le Cuit (Paris: Plon, 1964); Du miel aux cendres (Paris: Plon, 1966); L'origine des manières de table (Paris: Plon, 1968); L'homme nu (Paris: Plon, 1971). 
mently criticized for considering myth as only a manifestation of the underlying logic of the system in which it is a part, and not as a voicing and bodying forth of the inner life of humankind, of its achievements and tragedies, of recurrent experiences with wondrous and terrifying forces and movements, and least of all, of the drama inherent in human communication. The fascinating complexity and the range of Lévi-Strauss's inquiry into myth is meant to mask the fact that he has seriously isolated and narrowed the scope of his research, insofar as a general theory of society is concerned.

Lévi-Strauss is finally meant to have denatured the human mind by reducing it to a machine for producing logical rules. If myths can explain anything, critics wonder whether their reason is first of only intellectual character. It seems actually to Lévi-Strauss's critics that he only speaks of oppositions and transformations from one to another level with an approach that informs the application of his terms as thoroughly mechanistic. Technical procedures of structural analyses denying meaning at the level of action are taken to represent the most intellectualistic and abstracted approach to myth within the much broader spectrum of schools of thought. It is maintained that LéviStrauss's approach on the whole seems to lead away from, rather than into, questions about relations between mythologies and social systems, and about transformations in these relations as social systems change.

Moreover, because female sexuality and the wishes of women are superfluous to his kinship theory, Lévi-Strauss faced criticism from American feminists who began to make inroads in anthropology in the 1970s. In particular Gayle Rubin's chapter became the classic feminist critique of the structuralist position, presenting the whole of Lévi-Strauss's contribution as intrinsically reactionary. ${ }^{46}$ In addition, whereas in the 1970 s the feminists had regarded the Elementary Structures of Kinship ${ }^{47}$ as a treatise of sexism, it becomes homophobic with the recent movements for homosexual rights to marital union and parenthood..$^{48}$

No matter how many details Lévi-Strauss might have accounted for within his analytical framework, the motivating forces behind the process remained unintelligible and his procedures arbitrary, even if sometimes illuminating. ${ }^{49}$ Even the Tristes Tropiques ${ }^{50}$ have been criticized by theorists in cultural studies for almost everything, from racism to an oversimplification of

${ }^{46}$ Gayle Rubin, "The Traffic in Women: Notes on the Political Economy of Sex," in Toward an Anthropology of Women, ed. Rayna R. Reiter (New York: Monthly Review Press, 1975), 157-210.

${ }^{47}$ Claude Lévi-Strauss, Les structures elementaires de la parente (Paris: Mouton, 1967).

${ }^{48}$ Jeanne Favret-Saada, "La pensée Lévi-Strauss," Journal des Anthropologues, 82-83 (2000), 53-70; Patrice Maniglier, "L'humanisme interminable de Claude Lévi-Strauss," Les Temps Modernes, 609 (2000), 216-41.

${ }^{49}$ Roth, "Claude Levi-Strauss in Retrospect."

${ }^{50}$ Lévi-Strauss, Tristes Tropiques. 
the tropes of travel and fieldwork! ${ }^{51}$ Some authors like Jack Goody or Jacques Derrida have accused Lévi-Strauss of using ethnocentric categorizations, ${ }^{52}$ but the charge of racism is simply out of place. A full examination and reassessment of the far too many lines of criticism of Lévi-Strauss is beyond scope at this time. However, it can be said that the style of parody or pastiche can be quite popular among critics of Lévi-Strauss.

\section{The Anthropologist as a Hero}

It seems there is currently a total misrecognition of Lévi-Strauss's standing especially in contemporary American anthropology, where simply speaking, he seems to be on the verge of total irrelevance, as few practicing cultural anthropologists see themselves as at all influenced by his approach. At most, Lévi-Strauss is read in the context of the history of anthropology, and there he is usually dismissed, ironically for the very reason he must be praised, namely, his insistence on scientific rigor, simply because this concept is become unfortunately quite alien to many American cultural anthropologists. The result of this situation is less a steady critique of Lévi-Strauss than a particularly insouciant neglect. To put it bluntly, in the United States or Britain today, frequently graduate students of anthropology do not read LéviStrauss, who is even hardly mentioned in graduate courses, which is tragically shortsighted for the discipline. In addition, and what seems most dramatically critical is that most American anthropologists over the last three decades don't even think Lévi-Strauss is important enough to be argued with. He is simply ignored in the day-to-day practice of a discipline that by and large has embraced postmodernism.

The "tristes tropes" of postmodernists have located in empiricism and historicism a genuine and well-known problem, mainly by means of a dismissive attitude toward scientific analysis and the largely uncritical appropriation of literary criticism..$^{53}$ It is hardly surprising in these conditions that Derrida's theories have taken hold especially in North American departments of literature. In many ways his "deconstruction," grafted across the Atlantic from a set of European philosophical inquiries onto the terrain of American literary commentaries, is starting to look more American than French. It is often perceived even in Europe as an American brand of theorems, a discourse or a school, which has become known as a thoroughly American invention.

${ }^{51}$ James Clifford, Routes: Travel and Translation in the Late Twentieth Century (Cambridge, Mass.: Harvard University Press, 1997).

${ }^{52}$ Jack Goody, The Domestication of the Savage Mind (Cambridge: Cambridge University Press, 1977); Jacques Derrida, De la grammatologie.

${ }^{53}$ Nicole Polier and William Roseberry, "Tristes tropes: Post-modern Anthropologists Encounter the Other and Discover Themselves," Economy and Society, 18 (1989), 245-64. 
This, however, does not simply make reference to the fact that deconstruction is an American "thing," but also to the fact that only in America is this brand of deconstruction understood as a "thing" at all. In other words, it is not only in America that something like deconstruction is, but America itself is the deconstruction of Europe. ${ }^{54}$

No wonder there are and should be an increasing number of scholars, who have chosen other paths and do the work they do without recourse to LéviStrauss at all, in the wake of new developments in anthropology worldwide. But this cannot put at stake his contemporary relevance and his critical importance for the future, nor can this explain the negative trajectory of LéviStrauss's reputation, particularly in American cultural anthropology. Most anthropologists are rather unhappy with this situation, and Lévi-Strauss's theory is in fact received in anthropology with more discretion and undoubtedly in contrast with the critical reactions that the first texts of structural anthropology caused to a broad range of censors, more at ease to blame their philosophical presuppositions than to judge their impact in a field of knowledge that none really commanded.

Lévi-Strauss was truly an explorer finding his way into a new realm: a new world of myth and the imagination. In this respect his work dealt with both the analysis of the content of the myths and the mental processes that were responsible for their creation. Because such mythical contents and such mental processes had already been the subject of allegorist Frazerian exegesis or heated Freudian speculation respectively, Lévi-Strauss's writings acquired a significance far beyond the immediate realm of anthropological research. Litterateurs, psychologists, historians, and philosophers felt compelled to come to terms with Lévi-Strauss's radical views, but the fact that most of these hangers-on knew little about the technicalities of kinship systems, the exigencies of the ecology in the jungles of Brazil, or the debates around dual organization and similar matters meant that Lévi-Strauss himself became a mythical figure.

For many, Lévi-Strauss's theory is still too much "intellectualist" and prevent them from understanding the fascination of human action and practice. As if one rose up, for example, against the kinetic theory of gases under the pretext that by explaining why the hot air dilates and goes up, it would put in danger the life of family and the morals of the hearth whose demystified warmth would lose thus its symbolic and emotional resonances. As the fact of knowing, again, how the clock works inside would prevent us from knowing what role a watch might play in one's emotional life (making very impatient when an appointment is late, eager when the person one loves is about

\footnotetext{
${ }^{54}$ Anselm Haverkamp (ed.), Deconstruction is/in America (New York: New York University Press, 1995), 28.
} 
to arrive), or if the chemical formula of sugar deprived us of appreciating its savor and on the contrary would mistake us in preferring a salty or bitter taste.

Sensitive souls refuse to understand that there are not the emotions that produce culture but the opposite, just as music is a mathematical combination of different wavelengths that creates the emotions of which it is not the result. With his insistence upon a sharp separation between the collective and individual consciousness, Durkheim had failed to give proper emphasis to the possibility of understanding social facts totally. This corresponded, according to Lévi-Strauss, to a general fault of science whereby the subjective properties are left to one side while we seek explanations in purely objective forms. With his conception of "total social facts" Mauss implied that on the contrary this facile and convenient dichotomy is inadmissible for sociology:

In order to understand a social fact it is necessary to comprehend it totally, that is, from without as a thing, but a thing an integral part of which is also the subjective understanding, both conscious and unconscious, which we have of it, as if being inescapably human we were to live the fact as the native does instead of merely observing it as the ethnographer. ${ }^{55}$

As the ideal of a total chemistry that "ought to explain not only the form and distribution of the molecules of a strawberry but how a unique saviour does result from such a layout," Lévi-Strauss has tried to take things seriously, telling himself they are objects that require long and very patient analysis. ${ }^{56}$ Myth, for instance, is a sui generis reality that can and must be studied in its own right, without reference to a context, whether historical, psychological or sociological. Myths "are the very exercise of savage mind; their internal unity and logical coherence are not on the side of verisimilitude or reference." 57

Lévi-Strauss's theoretical interpretation, based on elucidation of the operations of human mind, realized a research of relationship between nature and culture, especially in the study of kinship systems and the production of myths. His originality was to challenge the dilemma of the incompatible conceptual opposition between human nature and cultural variety, attempting to show that one underlies the other in the way that an abstract and homogeneous structure controls concrete and varied manifestations. The principle is not new, it was held for asset in traditional philosophical anthropology, but modern ethnographic knowledge had called it into question. To rejoin this princi-

${ }^{55}$ Claude Lévi-Strauss, "Introduction a l'oeuvre de Marcel Mauss," in Marcel Mauss, Sociologie et Anthropologie (Paris: Presses Universitaires de France, 1950), xxviii.

${ }^{56}$ Claude Lévi-Strauss, ibid., xxvii.

${ }^{57}$ Marcel Henaff, Claude Levi-Strauss et l'anthropologie structurale (Paris: Belfond, 1991), 171. 
ple and challenge ethnographic empiricism, trying at the same time to identify universal laws of the human mind as they express themselves through such domains as kinship, myth, art, and "primitive" forms of classification, that is, better account for the cultural characteristics and to establish the intellectual unity of humankind, such is the task Lévi-Strauss was fixed.

Criticism was also the opportunity for Lévi-Strauss to assert his conviction that social sciences and anthropology, following the methodology of natural sciences, should understand that the reality of their subject matter is not entirely confined at the level of the observant subject. This is clear especially in the "finale" to the Mythologiques cycle, which can be seen as an extended defence of the structural method. In his attempt to clarify his divergences with the philosophies of the subject he also advocated a humanism less narrowly defined by the culture of one particular historical moment and reaffirmed, against Marxist criticism, his fidelity to Marx and the dialectical spirit of historical materialism. Trained as a philosopher, indeed, he never entirely abandoned philosophy, despite his protestations to the contrary, and wrote important critiques of both existentialism and phenomenology. One can see, in retrospect, the nature and the magnitude of the challenge Lévi-Strauss's anthropology posed to philosophy. The various criticisms leveled at structuralism, its reductionism, its antihumanism, and its a-historicism, are all countered, reformulated, and turned back against philosophy itself: its lack of scientific awareness, its ethnocentrism and anthropocentrism, its obsession with history.

As Leach reminded, Lévi-Strauss's importance lies in the mode of discourse he invented to display facts and frame explanations and ideas, suggesting new and unfamiliar ways of looking at familiar facts, and thereby provoking thought about fundamentals. ${ }^{58}$ In an astonishing chapter on "totem and caste," for example, Lévi-Strauss sets out to demonstrate that the structure of the Indian caste system is a logical transformation of the structure of the totemic order of Australian Aborigines. 59 "Intellectual firework" of this kind, in Leach's terms, do not in themselves enlarge our understanding of either the caste order or Australian totemism, but they do challenge us to think more deeply about human society and about what is specifically human. ${ }^{60}$ In Lévi-Strauss's view it is much more important to understand the difference between culture and nature than to bother with scholastic arguments about how oriental despotism, for instance, is related to feudalism in whatever sequence of historical determinism.

With his acknowledgment that mental satisfaction is a product of things

\footnotetext{
${ }^{58}$ Leach, Claude Levi-Strauss.

${ }^{59}$ Claude Lévi-Strauss, La pensee sauvage (Paris: Plon, 1962), 144-77.

${ }^{60}$ Leach, "Telstar et les aborigines ou la Pensee sauvage," 111.
} 
"good to think," ${ }^{61}$ he moved anthropology toward a more formal method and more scientific aspirations, and inadvertently ignited an intellectual enthusiasm that swept through nearly all social sciences and the humanities and made of him, in Susan Sontag's terms, the first anthropologist as a hero. ${ }^{62}$ But it is not the formalistic search for binary oppositions that is genuinely valuable, as it is not the odd facts or the even odder explanations Lévi-Strauss brought forth that made of him an intellectual hero. According to Clifford Geertz, no anthropologist has been more insistent than Lévi-Strauss on the fact that "the practice of his profession has consisted of a personal quest, driven by a personal vision, and directed toward a personal salvation." ${ }^{63}$ In the form of the standard prophetic myth of the heroic quest, with the anthropologist as its hero, as Richard Shweder put it, Lévi-Strauss transformed an expedition to the virgin interiors of the Amazon into a vision quest, and turned anthropology into a spiritual mission to defend mankind against itself.

That is why Lévi-Strauss is admired not so much for the novelty of his ideas as for the bold originality with which he seeks to apply them and for the range of associations whereby complexity appears as revealing instead of confusing. It is the organization of Lévi-Strauss's ideas that creates his facts "as a cyclotron creates subatomic particles." ${ }^{64} \mathrm{He}$ will no doubt be remembered for many things, including his skills as a meticulous researcher, whose command of detail was almost unprecedented, and as a scholar who never shied away from answering critics and who would at times revise ideas, when he felt the criticism to be serious and powerful enough. Yet, Lévi-Strauss's work is finally strange and more diverting than it appears. Rooted as it is in rationalism, it is also grafted on a paradoxical Rousseauism, but innerved of a twilight irony, that of an "active pessimism." If it intimidates by its radical power, it enchants by the delicacy of its ways of doing and captivates by the discernment with which it imposes its reasons. Written to convince, LéviStrauss's work is undoubtedly based on the irreproachable rigor of a scientific and academic discipline. At the same time, it is expressed in evocative prose that becomes poetic and limpid in his most difficult passes, swaying and subtle even in its most rectilinear and regulated course. It is full of savors, colored moods, woven in pleasures of writing, and unceasingly animated by a significant presence.

University of Limerick, Ireland and University College, London.

${ }^{61}$ Claude Lévi-Strauss, Le totemisme aujourd'hui (Paris: Presses Universitaires de France, 1962), 132.

${ }^{62}$ Nelson E. Hayes and Tanya Hayes (eds.), Claude Levi-Strauss: The Anthropologist as Hero (Cambridge, Mass.: Massachusetts Institute of Technology Press, 1970).

${ }^{63}$ Geertz, The Interpretation of Cultures, 346.

${ }^{64}$ Diamond, "The Inauthenticity of Anthropology." 